\title{
Quantifying and isolating stable soil organic carbon using long-term bare fallow experiments
}

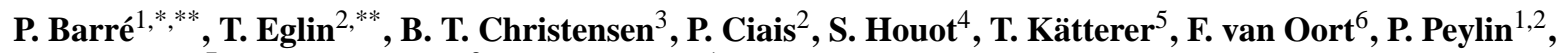 \\ P. R. Poulton ${ }^{7}$, V. Romanenkov ${ }^{8}$, and C. Chenu ${ }^{1}$ \\ ${ }^{1}$ BIOEMCO Laboratory, UMR ParisVI-ParisXII-AgroParisTech-CNRS-IRD-ENS, Campus Grignon, \\ 78850 Thiverval-Grignon, France \\ ${ }^{2}$ LSCE, UMR CEA-CNRS-UVSQ, CE L'Orme des Merisiers, 91191 Gif-sur-Yvette, France \\ ${ }^{3}$ University of Aarhus, Faculty of Agricultural Sciences, Department of Agroecology and Environment, 8830 Tjele, Denmark \\ ${ }^{4}$ EGC laboratory, UMR INRA-AgroParisTech, Campus Grignon, 78850 Thiverval-Grignon, France \\ ${ }^{5}$ Swedish University of Agricultural Sciences, Department of Soil and Environment, 75007 Uppsala, Sweden \\ ${ }^{6}$ PESSAC laboratory, INRA, 78026 Versailles, France \\ ${ }^{7}$ Rothamsted Research, Department of Soil Science, Harpenden, Herts, AL5 2JQ, UK \\ ${ }^{8}$ Pryanishnikov All Russian Institute for Agrochemistry VNIIA, Moscow 127550, Russia \\ *now at: Geology laboratory, UMR CNRS-ENS, Ecole normale supérieure, 75005 Paris, France \\ ** These authors contributed equally to this work.
}

Received: 14 June 2010 - Published in Biogeosciences Discuss.: 23 June 2010

Revised: 3 November 2010 - Accepted: 9 November 2010 - Published: 26 November 2010

\begin{abstract}
The stability of soil organic matter (SOM) is a major source of uncertainty in predicting atmospheric $\mathrm{CO}_{2}$ concentration during the $21 \mathrm{st}$ century. Isolating the stable soil carbon (C) from other, more labile, $\mathrm{C}$ fractions in soil is of prime importance for calibrating soil $\mathrm{C}$ simulation models, and gaining insights into the mechanisms that lead to soil $\mathrm{C}$ stability. Long-term experiments with continuous bare fallow (vegetation-free) treatments in which the decay of soil C is monitored for decades after all inputs of $\mathrm{C}$ have stopped, provide a unique opportunity to assess the quantity of stable soil C. We analyzed data from six bare fallow experiments of long-duration ( $>30 \mathrm{yrs}$ ), covering a range of soil types and climate conditions, and sited at Askov (Denmark), Grignon and Versailles (France), Kursk (Russia), Rothamsted (UK), and Ultuna (Sweden). A conceptual three pool model dividing soil C into a labile pool (turnover time of a several years), an intermediate pool (turnover time of a several decades) and a stable pool (turnover time of a several centuries or more) fits well with the long term $\mathrm{C}$ decline observed in the bare fallow soils. The estimate of stable $\mathrm{C}$ ranged from $2.7 \mathrm{~g} \mathrm{C} \mathrm{kg}^{-1}$ at Rothamsted to $6.8 \mathrm{~g} \mathrm{C} \mathrm{kg}^{-1}$ at Grignon. The uncertainty
\end{abstract}

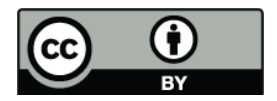

Correspondence to: P. Barré (barre@geologie.ens.fr) associated with estimates of the stable pool was large due to the short duration of the fallow treatments relative to the turnover time of stable soil C. At Versailles, where there is least uncertainty associated with the determination of a stable pool, the soil contains predominantly stable $\mathrm{C}$ after 80 years of continuous bare fallow. Such a site represents a unique research platform for characterization of the nature of stable SOM and its vulnerability to global change.

\section{Introduction}

The soil organic matter (SOM) contains about three times more carbon (C) than the atmosphere (Jobbagy and Jackson, 2000) and it is recognized that small but consistent changes in soil $\mathrm{C}$ have important consequences for atmospheric $\mathrm{CO}_{2}$ concentrations in the future (Cox et al., 2000). Levels of SOM are determined by soil texture, climate, inputs of organic material and its subsequent rate of decomposition, and the rate at which native SOM decomposes (Johnston et al., 2009). However, soil $\mathrm{C}$ dynamics are still discussed from the point of view of their sensitivity to climate and ecosystem productivity changes (Heimann and Reichstein, 2008). This has lead to a wide range in the global model predictions of future soil C storage (Friedlingstein et al., 2006; Sitch et al.,

Published by Copernicus Publications on behalf of the European Geosciences Union. 
2008). A better understanding of SOM stability and its vulnerability to land use change and to climate change as well as improved modeling of the soil $\mathrm{C}$ cycle are therefore crucial in order to provide more accurate predictions of future atmospheric $\mathrm{CO}_{2}$ concentration.

Using ${ }^{14} \mathrm{C}$ measurements (Trumbore et al., 1997; Jenkinson et al., 2008) and long-term $\mathrm{C}_{3} / \mathrm{C}_{4}$ vegetation changes (Balesdent et al., 1988), a fraction of the SOM has been shown to be hundreds to thousands of years old. In many respects, the stable SOM fraction remains terra incognita: mechanisms explaining its stability are still discussed (e.g. Fontaine et al., 2007; von Lützow et al., 2008) and its susceptibility to climate change intensively debated (Davidson and Janssens, 2006). In compartment models simulating soil C turnover, this stable SOM fraction is represented by a $\mathrm{C}$ pool with a slow turnover (several centuries) or even by an inert C pool (Falloon and Smith, 2000). However, the lack of knowledge on the characteristics of the stable SOM fraction remains critical for its modeling: the vulnerability to increased temperature of the stable $\mathrm{C}$ pool is unsettled (Knorr et al., 2005; Reichstein et al., 2005; Fang et al., 2006) and generally the size of the stable $\mathrm{C}$ pool is estimated from model outputs or is extrapolated from experiments 2 to 3 orders of magnitude shorter than the typical turnover time of the slowest $\mathrm{C}$ pools. A more detailed insight into the properties of this $\mathrm{C}$ pool is crucial as it represents a potentially large and long lasting sink for atmospheric $\mathrm{CO}_{2}$. Elliott et al. (1996) and Christensen (1996) challenged soil scientists and modelers to "measure the modelable or model the measurable". Here we aim at isolating the stable soil $\mathrm{C}$ pool from other $\mathrm{C}$ pools, using soils expected to contain very large proportions of stable $\mathrm{C}$.

One obvious way to assure that only stable $\mathrm{C}$ is present in a soil is to stop all $\mathrm{C}$ inputs and await the more labile compounds to decompose. Long-term bare fallow experiments (LTBF) provide such conditions. Bare fallow plots, included as reference treatments in several long-term agricultural experiments, have been kept free of plants by manual and/or chemical means for several decades. Although $\mathrm{C}$ inputs are not theoretically eliminated in bare fallow plots, due to atmospheric deposition, wind-blown particles and occasional weeds, such inputs can be considered as negligible as long as the bare fallow is suitably monitored and atmospheric deposition has been observed to be low. This was the case for all of the sites in this study. When bare fallow plots have been sampled regularly, one can measure directly the decay of the soil C initially present and estimate empirically, by assuming first order kinetics, the concentration of stable $\mathrm{C}$ and the uncertainty of that estimate. Until now, LTBF plots have not been compared across sites and examined in a modelling perspective. Moreover, they represent a unique opportunity for quantifying and characterizing stable soil $\mathrm{C}$ in different soils in particular when historic soil samples have been archived.
The objectives of present work were to: (i) initiate a network of LTBF experiments and synthesize the data from several sites; (ii) compare soil $\mathrm{C}$ decays with time in the LTBF plots; (iii) determine whether soil C decay in LTBF plots align with compartmental models with first order kinetics; (iv) estimate the stable $\mathrm{C}$ pool concentration and determine if it has been reached.

\section{Materials and methods}

\subsection{Descriptions of the sites included in the LTBF network}

Bare fallow experiments to be included in the network had to meet the following criteria: (i) plots kept vegetation-free and free of organic amendments for more than 25 years; (ii) regular measurements of the organic $\mathrm{C}$ in the tilled topsoil. An initial survey of Long Term Bare Fallow (LTBF) experiments identified six sites, all located in Europe: Askov (Denmark), Grignon and Versailles (France), Kursk (Russia), Rothamsted (UK) and Ultuna (Sweden). Selected characteristic data of these sites are presented in Table 1.

Potential Evaporation (PE in $\mathrm{mm}$ ) was calculated over the bare fallow duration using Penman equation (Penman, 1948):

$\mathrm{PE}=\sum_{t_{0}}^{t_{f}} \frac{\Delta \times\left(R_{\mathrm{n}}-G\right)+\times \gamma \times \lambda \times E_{a}}{\lambda \times(\Delta+\gamma)}$

where $\Delta$ is the slope of the saturated vapor pressure curve in $\mathrm{kPa}{ }^{\circ} \mathrm{C}^{-1}, \lambda$ is the latent heat of vaporization at $20^{\circ} \mathrm{C}$ $\left(=2.45 \mathrm{MJ} \mathrm{kg}^{-1}\right), R_{\mathrm{n}}$ is the net radiation flux in $\mathrm{MJ} \mathrm{m}^{-2} \mathrm{~d}^{-1}$, $G$ the heat flux into the soil in $\mathrm{MJ} \mathrm{m}^{-2} \mathrm{~d}^{-1}, \gamma$ is the psychrometric constant $\left(=0.066 \mathrm{kPA} 6 \circ \mathrm{C}^{-1}\right), \mathrm{E}_{a}$ is the vapor transport flux in $\mathrm{mm} \mathrm{d}^{-1}, t_{o}$ the time of the day of the bare fallow onset and $t_{f}$ the day of the last meteorological record.

$\Delta$ was calculated according to FAO -56 equation (Allen et al., 1998):

$\Delta=\frac{4.098 \times\left[0.6108 \times e^{\left(\frac{17.27 \times T}{T+237.3}\right)}\right]}{(T+237.3)^{2}}$

$E_{\mathrm{a}}$ was calculated as follows (Penman, 1948):

$E_{a}=\times 0.263 \times(1+0.537 \times u)\left(e^{0}-e_{a}\right)$

where $u$ is the wind speed in $\mathrm{m} \mathrm{s}^{-1}, e^{0}$ is the saturated vapor pressure in $\mathrm{kPa}$ and $e_{\mathrm{a}}$ is the mean ambient vapor pressure in $\mathrm{kPa}$.

\subsubsection{Askov}

The Askov bare fallow experiment was initiated in 1956 on the Askov Lermarken site. The experiment was adjacent to the B3- and B4-fields (blocks) of the Askov Long-Term Experiments on Animal Manure and Mineral Fertilizers (Christensen et al., 2006). The two blocks were analyzed separately 
Table 1. Selected site characteristics. The ratio annual precipitation/PE (P/PE) is a proxy for soil humidity. Soil masses used for $\mathrm{C}$ stock calculations correspond to the mass of soil in the sampled horizon at the last sampling date. Final $\mathrm{C}$ stocks refer to $\mathrm{C}$ mass in sampled horizon at the last sampling date. Initial $\mathrm{C}$ stocks refer to $\mathrm{C}$ mass in sampled horizon at the first sampling date plus the $\mathrm{C}$ mass that was in the soil below the sampling depth initially but in the sampling date eventually due to soil compaction. The uncertainties on $\mathrm{C}$ stocks derive from the uncertainties on SOC concentrations. The $\mathrm{C}$ concentration of this extra soil mass was considered to be $12 \mathrm{~g} \mathrm{C} \mathrm{kg}^{-1}$ at Rothamsted and $10 \mathrm{~g} \mathrm{C} \mathrm{kg}^{-1}$ at Versailles and Grignon (see Methods).

\begin{tabular}{|c|c|c|c|c|c|c|c|}
\hline Site & Kursk & Ultuna & Askov B3 & Askov B4 & Grignon & Versailles & Rothamsted \\
\hline Longitude/ & $51^{\circ} 73 \mathrm{~N}$ & $59^{\circ} 49 \mathrm{~N}$ & $55^{\circ} 28 \mathrm{~N}$ & $55^{\circ} 28 \mathrm{~N}$ & $48^{\circ} 51 \mathrm{~N}$ & $48^{\circ} 48 \mathrm{~N}$ & $51^{\circ} 82 \mathrm{~N}$ \\
\hline Latitude & $36^{\circ} 19 \mathrm{E}$ & $17^{\circ} 38 \mathrm{E}$ & $9^{\circ} 07 \mathrm{E}$ & $9^{\circ} 07 \mathrm{E}$ & $1^{\circ} 55 \mathrm{E}$ & $2^{\circ} 08 \mathrm{E}$ & $0^{\circ} 35 \mathrm{E}$ \\
\hline Dates & $1965-$ & $1956-$ & $1956-85$ & $1956-85$ & $1959-$ & $1928-$ & $1959-$ \\
\hline Last sampling date & 2001 & 2007 & 1985 & 1985 & 2007 & 2008 & 2008 \\
\hline History & Arable & Arable & Arable & Arable & Grassland & Grassland & Grassland \\
\hline Plot size (mxm) & $10 \times 10$ & $2 \times 2$ & $11.7 \times 9.4$ & $11.7 \times 9.4$ & $3.2 \times 3.2$ & $2 \times 2.5$ & $7 \times 12.5$ \\
\hline Number of replicates & 1 & 4 & 4 & 4 & 6 & 6 & 4 \\
\hline Sampling depth $(\mathrm{cm})$ & 25 & 20 & 20 & 20 & 25 & 25 & 23 \\
\hline Clay/Silt/Sand (\%) & $30 / 65 / 5$ & $36 / 41 / 23$ & $7 / 11 / 82$ & $7 / 11 / 82$ & $30 / 54 / 16$ & $17 / 57 / 26$ & $25 / 62 / 13$ \\
\hline Mean annual temperature $\left({ }^{\circ} \mathrm{C}\right)$ & 5.4 & 5.5 & 7.8 & 7.8 & 10.7 & 10.7 & 9.5 \\
\hline Annual precipitation (mm) & 574 & 533 & 862 & 862 & 649 & 628 & 712 \\
\hline $\mathrm{P} / \mathrm{PE}(\mathrm{mm} / \mathrm{mm})$ & 0.40 & 0.45 & 0.73 & 0.73 & 0.43 & 0.43 & 0.61 \\
\hline Initial bulk density $\left(\mathrm{kg} \mathrm{dm}^{-3}\right)$ & $1.13^{\mathrm{b}}$ & $1.44^{\mathrm{a}}$ & $1.50^{\mathrm{b}}$ & $1.50^{\mathrm{b}}$ & $1.20^{\mathrm{b}}$ & $1.30^{\mathrm{a}}$ & $0.94^{\mathrm{a}}$ \\
\hline Final bulk density $\left(\mathrm{kg} \mathrm{dm}^{-3}\right)$ & $1.13^{\mathrm{b}}$ & $1.43^{\mathrm{a}}$ & $1.50^{\mathrm{b}}$ & $1.50^{\mathrm{b}}$ & $1.21^{\mathrm{a}}$ & $1.44^{\mathrm{a}}$ & $1.43^{\mathrm{a}}$ \\
\hline Soil mass used for $\mathrm{C}$ stock calculations $\left(\mathrm{tha}^{-1}\right)$ & 2825 & 2860 & 3000 & 3000 & 3025 & 3600 & 3289 \\
\hline Initial $\mathrm{C}$ stock $\left(\mathrm{tC} \mathrm{ha}^{-1}\right)$ & 100.3 & $42.5 \pm 2.4$ & $52.1 \pm 5.9$ & $47.7 \pm 1.5$ & $41.6 \pm 2.7$ & $65.5 \pm 4.3$ & $71.7 \pm 2.0$ \\
\hline Final $\mathrm{C}$ stock $\left(\mathrm{tC} \mathrm{ha}^{-1}\right)$ & 79.4 & $26.9 \pm 0.6$ & $36.4 \pm 2.5$ & $33.0 \pm 1.3$ & $24.7 \pm 1.5$ & $22.7 \pm 3.3$ & $28.6 \pm 3.1$ \\
\hline
\end{tabular}

Bulk density values refer to measured (quoted by ${ }^{a}$ ) or estimated (quoted by ${ }^{b}$ ) values.

in the present work. The Lermarken site was first brought into cultivation around year 1800. According to Land Register maps from 1793, the site was at that time covered in open, mixed heath- and grassland with scattered deciduous scrubs. Most likely the area had historically been used for occasional haymaking and light grazing. The soil originates from morainal deposits and classifies as a Typical Hapludalf (USDA Soil Taxonomy) or Orthic Luvisol (FAO, 1989). The texture qualifies as a coarse sandy loam, the clay fraction being dominated by illite, smectite and kaolinite. The $\mathrm{pH}$ of the topsoil is kept at 5.5 to 6.5 by liming every 4 to 5 years. Soil bulk density is $1.50 \mathrm{~g} \mathrm{~cm}^{-3}$. Mean annual precipitation and temperature (1960-1990) is $862 \mathrm{~mm}$ and $7.7^{\circ} \mathrm{C}$. The plot size of the Askov LTBF was $11.7 \mathrm{~m} \times 9.4 \mathrm{~m}\left(110 \mathrm{~m}^{2}\right)$, with four replicate plots in both the B3- and the B4-field. The plots were kept free of vegetation by frequent tillage to $20 \mathrm{~cm}$ depth but received annual dressing of mineral NPK fertilizers. Bulk soil (composed of 9 to 11 cores) was sampled every year (spring) in the 0 to $20 \mathrm{~cm}$ depth of each replicate plot and analyzed for $\mathrm{C}$ content by dry combustion. The experiment was terminated in 1985, and further details on the experiment can be found elsewhere (Christensen, 1990; Christensen and Johnston, 1997; Bruun et al., 2003; Christensen et al., 2006).

\subsubsection{Grignon}

The Grignon LTBF experiment forms part of the larger 36-plot experiment, started in 1959 in the gardens of the "Chateau de Grignon". In this experiment, 6 treatments (bare fallow, bare fallow + nitrogen, straw, straw + nitrogen, composted straw and composted straw + nitrogen) were replicated 6 times in 6 blocks. Only the 6 bare fallow plots were used in the present study. Previous land use was unmanaged grassland since before 1875 . The soil is a silty loam classified as Agrudalf (USDA Soil Taxonomy) or Luvisol (FAO, 1989) and developed within a colluvial carbonated deposit, with $\mathrm{pH}$ (in water) of 8.0-8.3. The size of the plots is $3.2 \times 3.2 \mathrm{~m}^{2}$; all plots are dug by hand twice a year to $25 \mathrm{~cm}$ depth, and are kept free from vegetation by hand weeding and herbicide treatment. Soil C concentrations were measured by dry combustion. Further details on the experiment can be found elsewhere (Morel et al., 1984; Houot et al., 1989).

\subsubsection{Kursk}

The 45-year old Kursk continuous fallow field is located within the long-term field experiment of the Kursk Institute of Agro-Industrial Production in the Kursk Region of Russia. Formerly it was part of Kursk State Agriculture Experimental Station, Central Branch. The site was brought into cultivation more than 200 years before start of the experiment 
in 1964. The original vegetation was a steppe. The experiment $(355 \times 605 \mathrm{~m})$ was designed to compare dynamics of crop yield and soil parameters in 5-year rotations and continuous crops (corn, alfalfa, potatoes, winter wheat, peas) given two different background treatments- control and application of N200P250K150 and $20 \mathrm{tha}^{-1}$ farmyard manure per rotation. The site is located in the forest steppe climatic zone- temperate, moderately cold. The soil is a Haplic Chernozem (typical deep heavy loam chernozem on loess according to Russian classification). Initial soil $\mathrm{pH}(\mathrm{KCl})$ was 6.5 and exchangeable Ca $42 \mathrm{cmol}^{+} \mathrm{kg}^{-1}$. The large $(150 \times 14 \mathrm{~m})$ bare fallow plot has been ploughed to $22-25 \mathrm{~cm}$ twice every year. Weed growth has been controlled by periodic cultivation (usually up to 5 times per vegetation period) to a depth of $10 \mathrm{~cm}$. Mixed core samples were collected in 1965 and 1970 from $10 \times 10 \mathrm{~m}$ plots within a $18 \times 14 \mathrm{~m}$ part of the continuous fallow plot, followed by individual sampling in 1978, 1983, 1988 and 2001: 10 samples from 0-25 and 5 from $25-40 \mathrm{~cm}$. Soil $\mathrm{C}$ was analyzed by dry combustion.

\subsubsection{Rothamsted}

The Rothamsted Bare Fallow was started in December 1959 on a site which had been in managed grassland since 1838 . It is adjacent to a Ley-arable experiment which had started 11 years earlier and its purpose was to provide complementary data on changes in soil organic C. The soil is a flinty silty clay loam (Chromic Luvisol; FAO, 1989). The area of the site is ca. $50 \times 7 \mathrm{~m}$; this is divided into four sub-plots, each $12.5 \times 7 \mathrm{~m}$, for sampling purposes. Soils were sampled in December 1959 (immediately before the site was first ploughed) using semi-cylindrical augers and sampling to a depth of $23 \mathrm{~cm}$. It has been sampled on six occasions subsequently, most recently in September 2008. On two occasions, 1978 and 2000, soils were taken from the Bare Fallow and adjacent areas of permanent grass, with a sampling box (ca. $15 \times 15 \times 23 \mathrm{~cm}$ deep) to determine bulk density. In December 1959, organic $\mathrm{C}$ in the soil was $29.0 \mathrm{gC} \mathrm{kg}^{-1}$ and $\mathrm{pH}$ (in water) was 6.3; in 2008, organic $\mathrm{C}$ had declined to $10.0 \mathrm{gC} \mathrm{kg}^{-1}$ and $\mathrm{pH}$ to 5.2 . The site is kept free from weeds by ploughing/cultivating 2-4 times per year to 20 $22 \mathrm{~cm}$ depth; herbicides are used occasionally. Meteorological data is from a weather station ca. $200 \mathrm{~m}$ from the Bare Fallow site.

\subsubsection{Ultuna}

The "Ultuna continuous soil organic matter experiment" was started in 1956 on a field at the Swedish University of Agricultural Sciences that has probably been used for agriculture for several hundred years. The soil has been classified as a Typic Eutrochrept (USDA soil taxonomy) or Eutric Cambisol (FAO, 1989) (Kirchmann et al., 1996). The main aim of the experiment is to test the long-term effect of mineral fertilizers and organic amendments on crop yields and soil characteristics such as $\mathrm{C}$ content. The experiment consists of 15 treatments replicated in four blocks, 60 plots in total. The size of each plot is $2 \times 2 \mathrm{~m}$. The plots are separated with wooden frames that extend about $30 \mathrm{~cm}$ into the soil and about $10 \mathrm{~cm}$ above the soil surface. Since 1956, all cultivation has been performed manually with a spade to $20 \mathrm{~cm}$ depth. The soil was sampled using a soil corer at five random locations in each plot and combined to one composite sample before analysis. Soil $\mathrm{C}$ was analyzed using the WalkleyBlack method (total-C recovery factor of $77 \%$ (Bremner and Jenkinson, 1960)) from 1956 to 1983 and by dry combustion thereafter. The consistency of the $\mathrm{C}$ concentration data in the database was tested by comparing the $\mathrm{C}$ concentration determined with Walkley-Black method with those presented by Gerzabek et al. (1997), who re-analyzed archived soil samples (in one batch) by dry combustion for the period 1956 to 1993 using an element analyzer (Carlo Erba, 1500). Basic information and results for the first 35 years of the experiment were presented by Kirchmann et al. (1994). Earlier time series of $\mathrm{C}$ data from the bare fallow as well as other treatments have been used for calibrating and validating different soil C models (Andrén and Kätterer, 1997; Hyvönen et al., 1996; Paustian et al., 1992; Petersen et al., 2005)

\subsubsection{Versailles}

The Versailles LTBF experiment forms part of the larger 42-plot experiment that was initiated in 1928 at the Central Agronomy Station, which in 1946 became INRA. Located in the gardens of the 'Chateau de Versailles', this experiment was designed to study the effects of long-term application of fertilizers and amendments on the composition and physical properties of loess soils (Burgevin and Hénin, 1939). Previous land use was unmanaged grassland and forest before the 17th century. Ten of the 42 plots were used as bare fallow reference plots. Six plots sampled regularly since 1929 were analyzed for soil organic C content in 2009 and are included in this study. The soil is a silty loam Luvisol (FAO, 1989), developed within the aeolian loess covers that characterizes the Paris Basin. In 1929 the soil had a pH of 6.4 and a CEC of $15.3 \mathrm{cmol}^{+} \mathrm{kg}^{-1}$ (Cobaltihexamine method). Seventy years later (in 1999), the pH had decreased to 5.6 and the CEC to 8.7 (Pernes-Debuyser and Tessier, 2002). The size of the plots is $2 \times 2.5 \mathrm{~m}^{2}$. All plots are dug by hand twice a year to $25 \mathrm{~cm}$ depth, and are kept free from vegetation by hand weeding and herbicide treatment. Soil organic $\mathrm{C}$ concentrations were measured by dry combustion.

\subsection{Calculation of soil C stocks}

Initial and final soil $\mathrm{C}$ stocks were calculated on an equivalent soil mass basis. When bulk density was reported not to change (Ultuna), or could be assumed not to change (Askov, Grignon, Kursk), soil stock was calculated by multiplying the soil mass in the sampled horizon by the $\mathrm{C}$ concentration 
in the same layer. Bulk density was observed to increase with time at Rothamsted and Versailles. Due to increased bulk density, the sampled horizons contained a larger soil mass at the last sampling date than at the initial sampling date. To calculate $\mathrm{C}$ stocks on an equivalent soil mass basis, the $\mathrm{C}$ mass contained in the soil that was below the sampling depth initially but in the sampling horizon eventually was added to the $\mathrm{C}$ mass contained in the sampled horizon at the first sampling date (Jenkinson, 1971). The C concentration of the extra soil mass was assumed to be 12,11 and $10 \mathrm{gC} \mathrm{kg}^{-1}$ at Rothamsted in 1959, 1963 and from 1971 to 2009 respectively and $10 \mathrm{gC} \mathrm{kg}^{-1}$ throughout the experiments at Versailles. These values were estimated from $\mathrm{C}$ concentrations measured in soil horizons just below the sampling depth $(23-25 \mathrm{~cm}$ at Rothamsted and $25-40 \mathrm{~cm}$ at Versailles). For Rothamsted, where measurements of changes in bulk density with time are available $\left(0.94 \mathrm{~g} \mathrm{~cm}^{-3}\right.$ in 1959 , $1.01 \mathrm{~g} \mathrm{~cm}^{-3}$ in $1963,1.13 \mathrm{~g} \mathrm{~cm}^{-3}$ in 1971 and $1.25 \mathrm{~g} \mathrm{~cm}^{-3}$ since 1978), changes in the amount of $\mathrm{C}\left(\mathrm{tha}^{-1}\right)$ with time were calculated. Due to this bulk density increase, $\mathrm{C}$ stock values correspond to $0-30.7 \mathrm{~cm}$ in $1959,0-28.6 \mathrm{~cm}$ in 1963 , $0-25.3 \mathrm{~cm}$ in 1971 and $0-23 \mathrm{~cm}$ from 1978 to 2008 . For the other sites, only initial and final $\mathrm{C}$ stock values were calculated.

\subsection{Inverse modelling of soil C dynamics}

Linear $(y=a \times t+b)$, mono-exponential $(y=a \times \exp (-b \times t))$, mono-exponential + constant $(y=a \times \exp (-b \times t)+c)$, biexponential $(\mathrm{y}=\mathrm{a} \times \exp (-\mathrm{b} \times \mathrm{t})+\mathrm{c} \times \exp (-\mathrm{d} \times \mathrm{t}))$ and $\mathrm{bi}-$ exponential + constant $(\mathrm{y}=\mathrm{a} \times \exp (-\mathrm{b} \times \mathrm{t})+\mathrm{c} \times \exp (-\mathrm{d} \times \mathrm{t})$ $+\mathrm{e})$ models, where $t$ represents time under bare fallow and a, b, c, d, e are parameters, were fitted to each replicate using a Bayesian curve fitting method. Bayesian statistics are widely used in data assimilation communities where uncertain quantities (model parameters in our case) are optimized using uncertain results of an experiment (measurements) and a model linking the two spaces. In our case, this process allows us to include a priori information on the parameters that are sought for. Such formalism is general and may include the more classical parameter estimation process. We choose the Bayesian approach including a mismatch between model parameter estimates and their priors, weighted by the prior parameters uncertainty, as a very general approach widely used in inversion problems (Tarantola 1987; Santaren et al., 2007). Indeed, although our knowledge on the prior parameter is rather small, such formulation allows to account for it (i.e. to account for parameter errors and error covariances). For most sites, we choose "very large" dispersion (i.e. dispersions that are typically between 2 to 4 times the parameter values) and we verified that the results are rather independent to the choice of these errors. However for some sites and models if we use no prior information (i.e. extremely large errors) the algorithm becomes unstable with a solution oscillating during the minimisation process (iterative process) between different sets of parameter values. Some of these parameter sets are unrealistic given the physical law that we intended to represent with the model equations. The use of prior information, although rather large regularizes the inverse problem and leads to a physically acceptable and stable solution. We aimed to find a parameter set that minimized the difference between model outputs and the corresponding observations, considering model and data uncertainties, and prior information on parameters. With the assumption of Gaussian errors for both the observations and the prior parameters, the optimal parameter set corresponds to the minimum of the cost function $J(x)$ :

$$
\begin{aligned}
J(x) & =0.5\left[(\boldsymbol{y}-H(x))^{t} \mathbf{R}^{-1}(\boldsymbol{y}-H(x))\right. \\
& \left.+\left(x-x_{b}\right)^{t} \mathbf{P}_{b}^{-1}\left(x-x_{b}\right)\right]
\end{aligned}
$$

that contains both the mismatch between modeled and observed $\mathrm{C}$ content and the mismatch between a priori and optimized parameters. In the model $\boldsymbol{x}$ is the vector of unknown parameters, $\boldsymbol{x}_{\mathbf{b}}$ the vector of a priori value, $\mathrm{H}()$ the model and $\boldsymbol{y}$ the vector of observations. The covariance matrices $\mathbf{P}_{\mathrm{b}}$ and $\mathbf{R}$ describe a priori uncertainties on parameters and on observations, respectively. Both matrices are diagonal as we suppose the observation uncertainties and the parameter uncertainties to be independent. A very large a priori error on parameters was considered in order not to influence the fitting procedure (dispersions were typically between 2 to 4 times the parameter values and we verified that the results were independent of the choice of these errors). However, it was assumed that decay cannot be positive by defining a lognormal distribution for these parameters. For the data errors, we used the standard deviation estimated from 15 replicate determinations of $\mathrm{C}$ in soil samples taken from the same plot at Grignon in 1959. The measured standard deviation was $0.3 \mathrm{gC} \mathrm{kg}^{-1}$. As the $\mathrm{C}$ contents at the different LTBF sites were determined on composite samples from the same plot at each site, it was considered that the a priori error on measurements should be less than $0.5 \mathrm{gC} \mathrm{kg}^{-1}$ for every site. However, it appeared that the values of the cost function at the minimum (expressed as $\chi^{2}$ values) were too large for Askov, Kursk and Versailles, given the hypothesis of Gaussian errors we made. This suggests that data or parameter errors were too small. We thus increased the $0.5 \mathrm{gC} \mathrm{kg}^{-1}$ data error to $0.75 \mathrm{gC} \mathrm{kg}^{-1}$ for these sites, keeping large parameter errors not to nudge the solution. The new normalized $\chi^{2}$ values were all lower than 1 (a statistical criteria) and consequently considered as acceptable. Errors on measurements were therefore considered to be equal to $0.5 \mathrm{gC} \mathrm{kg}^{-1}$ for Grignon, Rothamsted and Ultuna and equal to $0.75 \mathrm{gC} \mathrm{kg}^{-1}$ for Askov, Kursk and Versailles. To determine an optimal set of parameters which minimizes $J(x)$, we used the BGFS gradient-based algorithm (Tarantola, 1987). The algorithm typically converged to a minimum of $J(x)$ within less than 5 iterations. We performed several optimizations starting with different parameter prior values to check that the results did not correspond to a local minimum. 

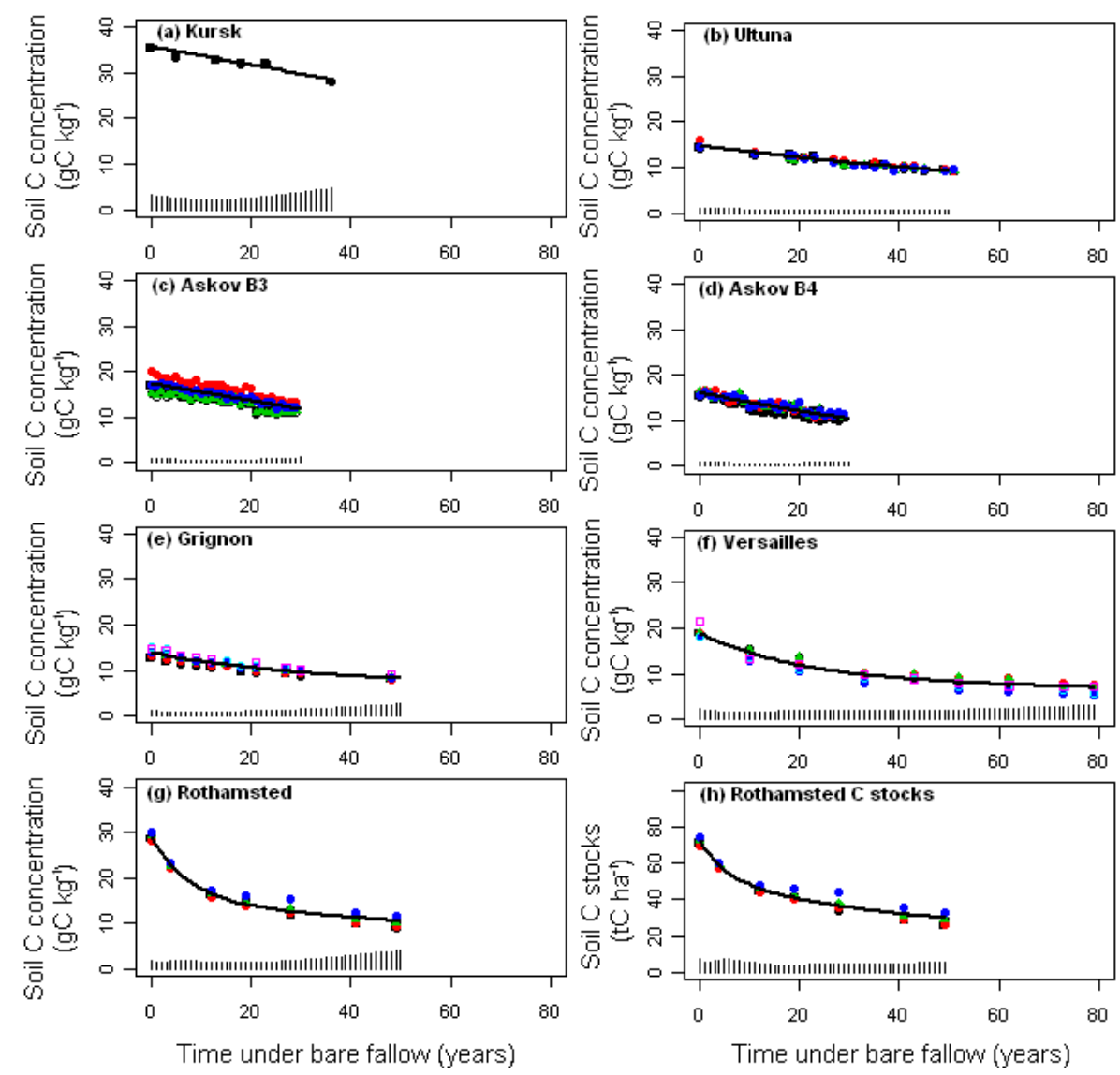

Fig. 1. Soil organic C decline with time in LTBF experiments. Different colors refer to different field replicates. The black lines represent the best fits. The best fits are linear for Kursk and Askov B3; mono-exponential for Ultuna and Askov B4; mono-exponential + constant for Grignon; bi-exponential for Versailles and Rothamsted and bi-exponential + constant for Rothamsted when working with $\mathrm{C}$ stocks. The residuals are equally distributed (mean of the residues lower than $0.01 \mathrm{gC} \mathrm{kg}^{-1}$ excepted at Kursk where it is equal to $0.085 \mathrm{gC} \mathrm{kg}^{-1}$ ) and did not present any trend with time. Vertical black bars correspond to the standard deviation multiplied by 4.

Once each replicate was fitted, plot-specific optimized parameters values were averaged at the site scale and the error covariance matrix of the parameters was estimated using the linearity assumption at the minimum of $J(x)$. The lines in Fig. 1 therefore represent the average of the different simulations at plot-scale and not a simulation with average parameters. This parameter error covariance matrix was also propagated on the model outputs, i.e. the predicted soil $\mathrm{C}$ content (95\% confidence interval in Fig. 1). For each site, best models were those with all parameters significantly different from zero (meaning that zero was not included in the 95\% confidence interval) and the lowest Akaike's information criterion (AIC) (Akaike, 1974). This criterion considers both the goodness of fit and the number of free parameters:

$\mathrm{AIC}=2 k+n[\ln (\mathrm{RSS} / n)]$

where $k$ corresponds to the number of free parameters, RSS is the residual sum of squares and $n$ the number of observations.
In a second step, it was considered that soil $\mathrm{C}$ decline should approach a positive plateau that would correspond to the stable $\mathrm{C}$ pool. For this second step, we assumed a lognormal distribution for the plateau parameter and the optimization was repeated. For each LTBF site, we assumed a priori that the plateau was embedded in a $95 \%$ confidence interval $\left[0.6 \mathrm{gC} \mathrm{kg}^{-1} ; 35.6 \mathrm{gC} \mathrm{kg}^{-1}\right]$.

\section{Results}

\subsection{Bulk density}

Bulk density has been determined at Rothamsted and Ultuna. At Rothamsted, the soil became more compact with time under bare fallow, whereas the bulk density did not vary significantly at Ultuna. At Versailles the void ratio and bulk densities were measured in 1929 and 2008 respectively. Assuming a $2.60 \mathrm{~g} \mathrm{~cm}^{-3}$ density for the solid phase of the soil, bulk density evolved from $1.30 \mathrm{~g} \mathrm{~cm}^{-3}$ in 1928 to $1.44 \mathrm{~g} \mathrm{~cm}^{-3}$ in 
2008. At Askov, the bulk density has been considered by Bruun et al., (2003) to be constant and equal to $1.50 \mathrm{~g} \mathrm{~cm}^{-3}$. At Kursk, a $1.13 \mathrm{~g} \mathrm{~cm}^{-3}$ bulk density was measured in 1983 (Lazarev, 2007). At Grignon, bulk density has been determined in the bare fallow plots and in the adjacent grassland in 2010 (Rémi Cardinael, unpublished data). Assuming that the bulk density of the grassland soil did not change between 1959 and 2010, it can be considered similar to the bulk density of the soil on which the bare fallow was initiated. As no significant difference between bare fallow and the adjacent grassland were observed $\left(1.20( \pm 0.06) \mathrm{g} \mathrm{cm}^{-3}\right.$ vs. $1.21( \pm 0.06) \mathrm{g} \mathrm{cm}^{-3}$, we conclude that introduction of bare fallow did not lead to significant changes in bulk density at Grignon. Initial and final soil $\mathrm{C}$ stock values calculated from measured or estimated bulk density are given in Table 1. However, due to the scanty information on soil bulk density, we mainly present changes in soil $\mathrm{C}$ concentrations (apart from Rothamsted, where changes in bulk density were the largest and for which the $\mathrm{C}$ stocks in the tilled layer as well as $\mathrm{C}$ concentrations will be discussed).

\subsection{Soil C losses under bare fallow treatments}

Changes in soil $\mathrm{C}$ concentrations with time in the topsoil at all sites are presented in Fig. 1. Initial $\mathrm{C}$ concentrations range from 13 to $20 \mathrm{gC} \mathrm{kg}^{-1}$ at Askov, Grignon, Ultuna and Versailles. Initial $\mathrm{C}$ concentration was larger at Rothamsted and even larger at Kursk, but soil $\mathrm{C}$ decreased with time at all sites. At Grignon and Versailles and especially at Rothamsted, where bare fallows were established on former grassland, soil C showed a steep initial decline, whereas sites previously in arable cropping showed a more constant decrease in soil $\mathrm{C}$ during the years that followed introduction of bare fallow. During the 10 first years, the annual soil $\mathrm{C}$ decrease rates averaged less than $1.6 \mathrm{gC} \mathrm{kg}^{-1}$ for sites previously under arable cropping and were above $3.5 \mathrm{gC} \mathrm{kg}^{-1}$ for sites on former grassland.

Figure $1 \mathrm{~h}$ shows the decrease in the amount of $\mathrm{C}$ for equivalent soil masses at Rothamsted (soil mass in the $0-23 \mathrm{~cm}$ horizon at the last sampling date was taken as reference). The shape of the decay curves for the amount and the concentration of $\mathrm{C}$ was similar. However, as bulk density increased rapidly during the first 19 years under bare fallow at Rothamsted, the initial $\mathrm{C}$ decrease is less dramatic when expressed as the quantity of $\mathrm{C}$ in equivalent soil masses. Indeed, after 19 years, the soil had lost $49 \%$ of its $C$ when based on concentration data but only $40 \%$ when based on the amount of soil C.

\subsection{Testing of simple compartmental models of soil C decay}

A linear model and first order models with up to three pools were successively fitted to the soil $\mathrm{C}$ concentration data using a least square minimization approach and assuming Gaussian errors for the data and the model. The best fits (lowest AIC value and all parameters significantly different from 0 ) for each site are plotted in Fig. 1 and Table 2 shows the AIC of all models.

Two-pool models performed better at sites formerly under grassland. For Grignon the model was a mono-exponential + constant, i.e. a bi-exponential model with the second exponential component equal to 0 . The best fit at Grignon suggests the existence of a $\mathrm{C}$ pool with a 33-year turnover time and a constant soil $\mathrm{C}$ plateau. Best fits at Rothamsted and Versailles do not show a plateau, but includes a second pool with a longer turnover time (150 and 350 years respectively). The first pool with exponential decay has a very short turnover time at Rothamsted (ca. 7.5 years) whereas it was longer at Grignon and Versailles (ca. 20 years). At Rothamsted, the bi-exponential model also performed best when working with soil C stocks. Contrary to Rothamsted, the initial steep $\mathrm{C}$ decline seen at Grignon and Versailles could not be described by a short-lived $\mathrm{C}$ pool. In contrast to the former grasslands, mono-exponential or linear fits performed better on sites formerly under arable cropping. The fits, with lower AIC, also gave soil C plateaus at Askov B4 and at Ultuna, but the plateaus were not significantly different from zero. At Askov B3 and Kursk, the data did not indicate the presence of a plateau.

\subsection{Comparing soil $\mathrm{C}$ development across sites}

It is necessary to apply the same, or at least comparable, models to all data when we compare soil $\mathrm{C}$ developments across sites. The mono-exponential + constant model appears to be the most appropriate for comparing sites: it is the best model at Grignon, it would have been the best at Askov B4 and Ultuna if the plateau estimates had been significant, and it performed reasonably well at all other sites except Rothamsted. However, it is comparable to a bi-exponential + constant model which did work quite well at Rothamsted. Therefore, a mono-exponential + constant model was applied to all dataset (except Rothamsted), and in this fitting procedure the constant was confined to a significant positive value using a lognormal transformation. Within the conceptual framework of three $\mathrm{C}$ pools, the exponential part reflects the decay of an intermediate SOM pool (or a mixed pool also including labile material), and the constant is the stable pool (truly inert or decomposing so slowly that it appears inert at the time scale of the experiment). For the Rothamsted dataset, a bi-exponential + constant model (a labile, an intermediate, and a stable pool) with a forced positive constant was applied. The SOM responsible for the initial steep decay at Versailles and Grignon (probably corresponding to labile SOM) was thereby incorporated into the intermediate pool. To test the influence of labile $\mathrm{C}$ on the decay rate of the intermediate pool and the concentration of the stable pool, mono-exponential + constant fits were also applied to Versailles and Grignon dataset after excluding data from the first 
Table 2. Akaike's Information Criterion values ("AIC") of all tested models. Best fits (in bold) are the fits with the lowest AIC and all parameters significant. $\mathrm{C}=\mathrm{ns}$ means that the constant value is not different from 0 .

\begin{tabular}{lrrrcc}
\hline \multirow{2}{*}{ Site } & \multicolumn{5}{c}{ Model } \\
\cline { 2 - 6 } & Linear & $\begin{array}{r}\text { Mono- } \\
\text { exponential }\end{array}$ & $\begin{array}{c}\text { Mono- } \\
\text { exponential + constant }\end{array}$ & $\begin{array}{c}\text { Bi- } \\
\text { exponential }\end{array}$ & $\begin{array}{c}\text { Bi-exponential } \\
+ \text { constant }\end{array}$ \\
\hline Kursk & $\mathbf{- 2 . 8}$ & -2.2 & $-1.2(\mathrm{C}=\mathrm{ns})$ & $/$ & $/$ \\
Ultuna & -128.7 & $-\mathbf{1 4 4 . 3}$ & $-150.6(\mathrm{C}=\mathrm{ns})$ & $/$ & $/$ \\
Askov B3 & $-\mathbf{1 5 6 . 4}$ & -147.3 & $-146.3(\mathrm{C}=\mathrm{ns})$ & $/$ & $/$ \\
Askov B4 & -114.5 & $-\mathbf{1 2 6 . 0}$ & $-133.0(\mathrm{C}=\mathrm{ns})$ & $/$ & $/$ \\
Grignon & -93.7 & -128.5 & $-\mathbf{2 0 0 . 2}$ & -198.4 & $/$ \\
Versailles & 64.8 & 20.4 & -76.1 & $-\mathbf{8 2 . 3}$ & $-81.0(\mathrm{C}=\mathrm{ns})$ \\
Rothamsted & 63.4 & 44.2 & -10.2 & $-\mathbf{6 3 . 4}$ & $-62.9(\mathrm{C}=\mathrm{ns})$ \\
Rothamsted stock & 118.4 & 94.2 & 45.2 & $\mathbf{2 1 . 7}$ & $8.2(\mathrm{C}=\mathrm{ns})$ \\
\hline
\end{tabular}

Table 3. Akaike's information criterion values ("AIC") of the mono-exponential + forced positive constant fits, current estimation of the turnover times and concentration of the $\mathrm{C}$ in the stable pool and size of the stable pool in the sampled horizon. $95 \%$ confidence intervals are associated to the estimation of the stable pool concentration and size and turnover times of labile and intermediate pools.

\begin{tabular}{lccrrr}
\hline Site & “AIC" & $\begin{array}{r}\text { Labile turnover } \\
\text { time (years) }\end{array}$ & $\begin{array}{r}\text { Intermediate turnover } \\
\text { time (years) }\end{array}$ & $\begin{array}{r}\text { Stable pool concentration } \\
\left(\mathrm{gC} \mathrm{kg}^{-1}\right)\end{array}$ & $\begin{array}{r}\text { Stable pool size } \\
\left(\mathrm{tC} \mathrm{ha}^{-1}\right)\end{array}$ \\
\hline Kursk & -1.2 & $/$ & $133.3(84.0-204.1)$ & $2.97(0.66-35.60)$ & $8.4(1.9-100.6)$ \\
Ultuna & -146 & $/$ & $66.2(44.8-99.0)$ & $3.90(1.93-9.17)$ & $11.2(5.6-26.4)$ \\
Askov B3 & -143 & $/$ & $65.4(51.8-81.3)$ & $2.48(1.05-7.46)$ & $7.4(3.2-22.4)$ \\
Askov B4 & -132 & $/$ & $38.0(27.2-51.9)$ & $4.39(2.10-10.84)$ & $13.2(6.3-32.5)$ \\
Grignon & -93 & $/$ & $30.3(17.5-50.0)$ & $6.80(4.86-9.82)$ & $22.6(16.2-32.7)$ \\
Grignon truncated & -104 & $/$ & $74.6(46.7-113.6)$ & $3.26(1.59-7.83)$ & $10.8(5.3-26.0)$ \\
Versailles & -76 & $/$ & $24.4(20.4-28.6)$ & $6.12(5.47-6.87)$ & $22.0(19.7-24.7)$ \\
Versailles truncated & -88 & $/$ & $18.2(7.2-38.3)$ & $5.87(4.56-7.68)$ & $21.1(16.4-27.6)$ \\
Rothamsted & -61.5 & $5.2(4.1-6.7)$ & $60.9(38.9-95.6)$ & $2.72(1.05-7.03)$ & $8.9(3.5-23.1)$ \\
\hline
\end{tabular}

10 or 12 years, respectively ( plots were sampled after 10 years at Versailles and 12 years at Grignon). These dataset are referred to as "Versailles-" and "Grignon truncated".

Table 3 reports the turnover time of the intermediate soil $\mathrm{C}$ pool (years), the concentration of stable $\mathrm{C}\left(\mathrm{gC} \mathrm{kg}^{-1}\right.$ soil) and its quantity in the sampled horizon $\left(\mathrm{t} \mathrm{Cha}^{-1}\right)$, and the AIC values of each fit. The differences among sites are not substantial but the $95 \%$ confidence intervals are very wide for every parameter. The turnover time of the intermediate $\mathrm{C}$ pools ranged from ca. 21 years at Versailles to 133 years at Kursk. The turnover time of the intermediate pool was significantly longer at Kursk than elsewhere except Ultuna, Rothamsted and Grignon truncated. The turnover time was significantly shorter at Versailles than at other sites except Askov B4 and Grignon. There was no significant difference between the estimates of the stable $\mathrm{C}$ pool across the sites. At this stage of fitting, the models predict $3-4 \mathrm{~g}$ of stable $\mathrm{C}$ per $\mathrm{kg}$ of soil for all sites but Versailles and Grignon. It is worth noting that the uncertainty on the estimated plateau at Kursk is the same as the a priori uncertainty, showing that the present dataset does not provide any constraints on the plateau value. Leaving out the first 10 or 12 years increased the turnover time of the intermediate $\mathrm{C}$ pool and reduced the concentration and quantity of the stable $\mathrm{C}$ at Grignon, but not at Versailles.

Figure 2 shows that the modeled concentration of stable soil $\mathrm{C}$ and the $\mathrm{C}$ concentration measured in bare fallow soils at the last sampling in 2008 at Versailles are almost similar both for truncated and non-truncated data.

\section{Discussion}

\subsection{Bare fallow data aligns with the three pool concept of soil C models}

Most simulation models divide SOM into three C pools: a labile pool (turnover time of several years), an intermediate pool (turnover time of several decades) and a stable $\mathrm{C}$ pool (turnover time of several centuries or more). Delineation of 


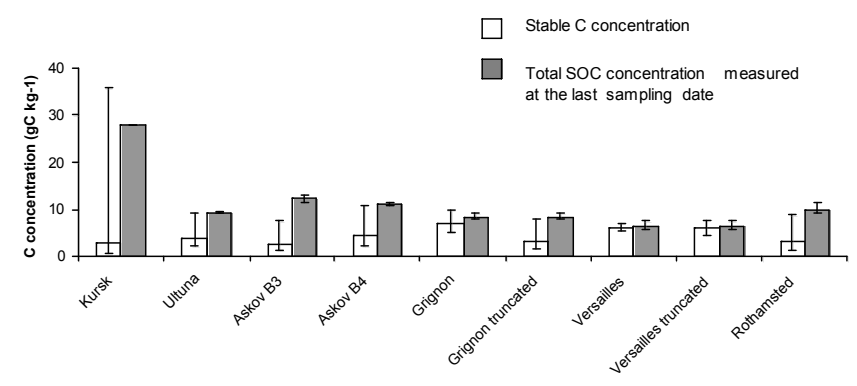

Fig. 2. Estimated stable pool concentration and soil $\mathrm{C}$ concentration measured at the last sampling date. Error bars refer to the $95 \%$ confidence interval for the stable $\mathrm{C}$ concentration and to minimal and maximal replicate values for the $\mathrm{C}$ concentration measured at the last sampling date.

a short-lived labile $\mathrm{C}$ pool using long-term soil $\mathrm{C}$ data is not meaningful because this pool is minute compared to the other $\mathrm{C}$ pools (e.g. $\approx 1 \%$ of total soil $\mathrm{C}$ in the Century model (Kelly et al., 1997)) and is by definition rapidly exhausted. Our results indicate that soil $\mathrm{C}$ in all but one of the LTBF soils can be described by one pool with a turnover of several decades and one stable pool. The exception is Rothamsted where three pools can be observed. This is due to the initial rapid decline in soil $\mathrm{C}$ which reflects a labile pool with short turnover time. Considering that we have probably missed the decay of similar labile pools at the other sites, we conclude that our analysis of the assembled LTBF dataset aligns with a three pool structure and first order decay kinetics shared by most compartment models simulating SOM turnover in soil (e.g. Parton et al., 1987; Coleman et al., 1996).

Bare fallows following grassland exhibited a steeper initial decrease in soil $\mathrm{C}$ than bare fallows established after arable cropping. This suggests that there is more labile SOM in grassland than in arable soils. Two complementary explanations can be proposed: (i) the tillage of the grasslands that initiates bare fallowing and tillage during the initial phase of bare fallow treatments release labile SOM that becomes mineralized rapidly following deprotection; (ii) the grasslands contain more root-derived $\mathrm{C}$ than arable surface soils (Jackson et al., 1996) and the initial drop in soil C at the former grassland sites represents enhanced mineralization in grassland soils when these are turned into bare fallow. Roots and other plant residues $>2 \mathrm{~mm}$ are usually removed when soil is sampled for $\mathrm{C}$ determination. Although root exudates and fine roots contribute to the soil $\mathrm{C}$ content, such $\mathrm{C}$ inputs to the soil can only partly account for the $12 \mathrm{~g} \mathrm{C} \mathrm{kg}^{-1}$ (approximately $25 \mathrm{tC} \mathrm{ha}^{-1}$ ) lost during the first ca. 12 years at Rothamsted. Consequently, tillage-induced deprotection of labile SOM probably explains most of the steep initial decrease in soil C observed at Grignon, Rothamsted and Versailles. The fitting routine did not propose a separate labile $\mathrm{C}$ pool at Versailles and Grignon indicating that the labile pool was much larger at Rothamsted than at the other two sites.
This is ascribed to Rothamsted being the only site where the first samples were taken before the grassland was terminated.

The estimated turnover times of the labile and intermediate $\mathrm{C}$ at Rothamsted using calculated $\mathrm{C}$ stocks were not significantly different from those based on $\mathrm{C}$ concentrations. As bulk density change was by far the most important at Rothamsted, we consider that ignoring or taking into account bulk density modifications do not affect our results significantly. Consequently, our turnover time values estimated from SOC concentration data can be compared to those of SOC models running usually on $\mathrm{C}$ stock data. Turnover times inferred from the LTBF experiments for the labile (i.e. 5.2 years at Rothamsted) and intermediate (i.e. 18-133 years) C pools agree with those of the active and slow pools of the Century model (Parton et al., 1987) and those of the microbial biomass and humified organic matter of Roth-C (Coleman et al., 1996). In these models, pedo-climatic factors regulate the decay rate of soil $\mathrm{C}$ pools, using empirical relationships that are difficult to address with our LTBF data due to the large errors associated with the fitted parameters (suggesting that longer experimental period is required to obtain better constraints on these parameters) and the small number of sites. Inclusion of more LTBF experiments established on different soil types, especially in warmer locations, would provide larger contrasts in the pedo-climatic factors. The relatively slow turnover observed at Kursk can be qualitatively explained by a cold and dry site with a very low sand content.

\subsection{Estimating the stable soil C pool using LTBF data}

The fitting procedure gave estimates for the concentration of stable soil C pool, which were approximately $6 \mathrm{gC} \mathrm{kg}^{-1}$ for Versailles (truncated or not) and Grignon and $3-4 \mathrm{gC} \mathrm{kg}^{-1}$ (near the a priori value) at Kursk, Askov, Ultuna, Rothamsted and Grignon truncated, but with large uncertainties. The decline in soil $\mathrm{C}$ at Grignon, Rothamsted and Ultuna suggests that the plateau value eventually reached will be higher than the average estimate. Altogether these results agree well with Balesdent et al. (1988) who found a stable C pool of ca. $7 \mathrm{gC} \mathrm{kg}^{-1}$ using a $\mathrm{C}_{3} / \mathrm{C}_{4}$ vegetation chronosequence.

The estimated stable soil $\mathrm{C}$ concentrations are in accordance with values for the passive pool found with the Century model (Kelly et al., 1997) and aligns with estimates of the size of compartments with long turnover times in other models such as CN-SIM (Petersen et al., 2005) and Daisy (Bruun et al., 2003). The unique datasets assembled by the LTBF network therefore supports experimentally the values for stable soil $\mathrm{C}$ concentrations estimated by compartment models that simulate the long-term dynamics of $\mathrm{C}$ in soil. The size of the stable $\mathrm{C}$ pool inferred from the LTBF data is however 2 to 7 times larger than the inert $\mathrm{C}$ pool defined in the Roth-C model (Coleman and Jenkinson, 1996; Coleman et al., 1997; Falloon et al., 1998), a discrepancy that could have a strong impact on the outcome of long-term simulations of the terrestrial $\mathrm{C}$ balance. 
As for turnover of the intermediate pool values, it is difficult to discuss factors influencing stable pool concentrations due to the large errors on the fit parameters and the small number of sites. Moreover, a large part of the stable $\mathrm{C}$ pool formed several centuries ago when no information on management and site history were available. The impact of this poorly constrained site history, at the time scale of stable $\mathrm{C}$ formation, on stable $\mathrm{C}$ concentration is potentially important. In particular, black $\mathrm{C}(\mathrm{BC})$ can represent an important part of the stable $C$ pool (Lehmann et al., 2008). If most of stable $C$ is due to $\mathrm{BC}$, its concentration would be much more related to site history (for instance occurrence of fires during the last millennia) than present pedoclimatic parameters.

\subsection{Soil containing mainly stable $C$ : new research opportunities}

Soil C concentrations measured in 2008 in the Versailles bare fallow soil averaged $6.30 \pm 0.93 \mathrm{gC} \mathrm{kg}^{-1}$. Comparing this value with the estimated concentration of stable $\mathrm{C}$ pool (assessed from our model-data fit), we can deduce that at least $73 \%$ of the $\mathrm{C}$ in this soil is in stable SOM. At Grignon, the present soil $\mathrm{C}$ concentration is close to the stable pool estimate when considering the entire dataset (i.e. without excluding the first 12 years). At the other sites, estimating the proportion of stable $\mathrm{C}$ pool is difficult, due to the large uncertainties associated with the estimates. But recalling the possible under-estimation of the plateau value at Grignon, Rothamsted and Ultuna, a stable soil C plateau will also be reached at these sites within decades.

Even though LTBF sites have been used in several studies addressing stable C (e.g. Kiem and Kögel-Knabner, 2002; Kiem et al., 2002; Plante et al., 2005), they have not yet been considered as a resource with which to address the challenge posed by Elliott et al. (1996) and Christensen (1996) to soil $\mathrm{C}$ scientists to "measure the modelable or model the measurable". Most of the organic C in the surface soil of the bare fallow at Versailles appears to belong to the stable $\mathrm{C}$ pool. Together with archived soils from historical samplings of the fallow plots and soils from adjacent plots under different land uses, the soil present today may allow us to approach "the modelable". The delineation of stable $\mathrm{C}$ from the other soil $\mathrm{C}$ pools provides an opportunity to identify the mechanisms behind the long-term stabilization of SOM. Moreover, this soil could also be used to test experimentally the vulnerability of stable soil $\mathrm{C}$ to global change and provide insights into the relative sensitivities of labile, intermediate and stable SOM components to increased temperature (Giardina and Ryan, 2000; Knorr et al., 2005; Fang et al., 2005, 2006).

LTBF samples are also a unique tool to determine the quantitative importance of $\mathrm{BC}$ in stable $\mathrm{C}$ pool concentration. Indeed, the presence of $\mathrm{BC}$ has been reported at Versailles (probably due to the initial clearing of the forest between the 17 th and the 19th centuries) and might be also present at the other sites (BC has been reported in some soils of the Park
Grass experiment at Rothamsted near the old Manor House (Jenkinson et al., 2008), but there has been no evidence for the presence of coal in the bare fallow experiment plots yet). The comparison of BC content in actual LTBF samples with stable $\mathrm{C}$ pool concentration estimates, will allow one to discuss the percentage of stable $\mathrm{C}$ that is $\mathrm{BC}$ which would be an important insight for improving the calibration of the stable $\mathrm{C}$ pool in soil $\mathrm{C}$ models.

\section{Conclusions}

This study initiated a network of six LTBF sites. The compilation of data from these sites constitutes a unique dataset to investigate soil $\mathrm{C}$ dynamics, and data from each site is accessible upon request to the data holders. The analysis of our dataset by inverse modelling revealed that soil $\mathrm{C}$ decay in LTBF soils can be represented by a mono-exponential + constant function. The exponential component corresponds to the decay of an intermediate $\mathrm{C}$ pool (turnover time from 18 to 133 years) and the constant to a stable $\mathrm{C}$ pool. The stable pool may correspond to SOM that has been protected against decomposition since the start of the LTBF, or a pool that decomposes so slowly that it can be considered as inert over the duration of the experiment. At Rothamsted, a component representing short-lived exponential decay of a labile $\mathrm{C}$ pool had to be added to the mono-exponential + constant function. This difference can be explained by a different land-use history. Our analysis does not contradict but rather aligns with the three pool concept used in many soil C compartment models, recalling that the labile pool (usually representing ca. $1 \%$ of soil C in such models) was not observed, except at Rothamsted. The stable C pool inferred from inverse modelling constituted a significant part (ca. 25\%) of the total soil $\mathrm{C}$ content. Analyses of $\mathrm{BC}$ concentrations in archived and new LTBF soil samples may allow clarification of the role of $\mathrm{BC}$ in the stable $\mathrm{C}$ pools. Apart from Versailles, large uncertainties are associated with the estimates of stable soil $\mathrm{C}$ and longer bare-fallow treatments are required to determine the stable $\mathrm{C}$ pool more precisely. Modeling of the data from the LTBF plots at Versailles suggests that these soils contain predominantly stable C. Soils at the other LTBF sites are enriched in stable $\mathrm{C}$ but still contain a substantial amount of intermediate $\mathrm{C}$.

Acknowledgements. We gratefully recognize the efforts of the people who initiated and maintained the LTBF experiments and who thereby made it possible for us to undertake this study. We thank Daniel Billiou who determined $\mathrm{C}$ concentrations in the Grignon and Versailles soil samples and Jean Pierre Petraud who coordinated the 2008 Versailles sampling. We gratefully acknowledge Elly M. Hansen, Boris Kogut and Eric Dufrêne for their valuable comments on the dataset. The comments provided by Alain F. Plante, Sander Bruun, Benedikt Scharnagel, Jens Leifeld and one anonymous reviewer on earlier versions of the manuscript are much appreciated.

Edited by: J. Leifeld 


\section{References}

Akaike, H.: A new look at the statistical model identification, IEEE T. on Automat. Cont., 19, 716-723, 1974.

Allen, R. G., Pereira, L. S., Raes, D., and Smith, M.: Crop evapotranspiration - guidelines for computing crop water requirements, Food and Agricultural Organization of the United Nations (FAO) Irrigation and Drain, Paper No 56, Rome, 1998.

Andrén, O. and Kätterer, T.: ICBM: The introductory carbon balance model for exploration of soil carbon balances, Ecol. Appl., 7, 1226-1236, 1997.

Balesdent, J., Wagner, G. H., and Mariotti, A.: Soil organic matter turnover in long-term field experiments as revealed by C-13 natural abundance, Soil Sci. Soc. Am. J., 52, 118-124, 1988.

Bremner, J. M. and Jenkinson, D. S.: Determination of organic carbon in soil, J. Soil Sci., 11, 394-402, 1960.

Bruun, S., Christensen, B. T., Hansen, E. M., Magid, J., and Jensen, L. S.: Calibration and validation of the soil organic matter dynamics of the Daisy model with data from the Askov long-term experiments, Soil Biol. Biochem., 35, 67-76, 2003.

Burgevin, H. and Hénin, S.: Dix années d'expériences sur l'action des engrais sur la composition et les propriétés d'un sol de limon (in French), Ann. Agron., 9, 771-799, 1939.

Christensen, B. T.: Effect of cropping system on the soil organic matter content II, Field experiments on a sandy loam 1956-1985 (in Danish with English summary), Tidsskrift for Planteavl, 94, 161-169, 1990.

Christensen, B. T.: Matching measurable soil organic matter fractions with conceptual pools in simulation models of carbon turnover: Revision of model structure, in: Evaluation of soil organic matter models using existing, long-term datasets, edited by: Powlson, D. S., Smith, P., and Smith, J. U., NATO ASI Series I, Springer, Berlin, 38, 143-159, 1996.

Christensen, B. T. and Johnston, A. E.: Soil organic matter and soil quality - lessons learned from long-term experiments at Askov and Rothamsted, Dev. Soil Sci., 25, 399-430, 1997.

Christensen, B. T., Petersen, J., and Trentemoller, U.,M.: The Askov Long-term Experiments on Animal Manure and Mineral Fertilizers: The Lermarken site 1894-2004, DIAS Report Plant Production no. 121, Danish Institute of Agricultural Sciences, Tjele, Denmark, 2006.

Coleman, K. and Jenkinson, D. S.: RothC-26.3 - A model for the turnover of carbon in soil, in: Evaluation of soil organic matter models using existing, long-term datasets, edited by: Powlson, D. S., Smith, P., and Smith, J. U., NATO ASI Series I, Springer, Berlin, 38, 237-246, 1996.

Coleman, K., Jenkinson, D. S., Crocker, G. J., Grace, P. R., Klir, J., Korschens, M., Poulton, P. R., and Richter, D. D.: Simulating trends in soil organic carbon in long-term experiments using RothC-26.3, Geoderma, 81, 29-44, 1997.

Cox, P. M., Betts, R. A., Jones, C. D., Spall, S. A., and Totterdell, I. J.: Acceleration of global warming due to carbon-cycle feedbacks in a coupled climate model, Nature, 408, 184-187, 2000.

Davidson, E. A. and Janssens, I. A.: Temperature sensitivity of soil carbon decomposition and feedbacks to climate change, Nature, 440, 165-173, 2006.

Elliott, E. T., Paustian, K., and Frey, S. D.: Modeling the measurable or measuring the modelable: A hierarchical approach to isolating meaningful soil organic matter fractionations, in: Evaluation of soil organic matter models using existing, long-term datasets, edited by: Powlson, D. S., Smith, P., and Smith, J. U., NATO ASI Series I, Springer, Berlin, 38, 161-179, 1996.

Falloon, P., Smith, P., Coleman, K., and Marshall, S.: Estimating the size of the inert organic matter pool from total soil organic carbon content for use in the Rothamsted carbon model, Soil Biol Biochem., 30, 1207-1211, 1998.

Falloon, P. and Smith, P.: Modelling refractory soil organic matter, Biol. Fert. Soils, 30, 388-398, 2000.

Fang. C., Smith, P., Moncrieff, J. B., and Smith, J. U.: Similar response of labile and resistant soil organic matter pools to changes in temperature, Nature, 433, 57-59, 2005.

Fang, C., Smith, P., and Smith, J. U.: Is resistant soil organic matter more sensitive to temperature than the labile organic matter?, Biogeosciences, 3, 65-68, doi:10.5194/bg-3-65-2006, 2006.

FAO: Soil map of the world. ISRIC, Technical Paper 20, Wageningen, The Netherlands, 1989.

Fontaine, S., Barot, S., Barre, P., Bdioui, N, Mary, B., and Rumpel, C.: Stability of organic carbon in deep soil layers controlled by fresh carbon supply, Nature, 450, 277-281, 2007.

Friedlingstein, P., Cox, P., Betts, R., Bopp, L., Von Bloh, W., Brovkin, V., Cadule, P., Doney, S., Eby, M., Fung, I., Bala, G., John, J., Jones, C., Joos, F., Kato, T., Kawamiya, M., Knorr, W., Lindsay, K., Matthews, H. D., Raddatz, T., Rayner, P., Reick, C., Roeckner, E., Schnitzler, K.-G., Schnur, R., Strassmann, K., Weaver, A. J., Yoshikawa, C., and Zeng, N.: Climate-carbon cycle feedback analysis: Results from the (CMIP)-M-4 model intercomparison, J. Climate, 19, 3337-3353, 2006.

Gerzabek, M. H., Pichlmayer, F., Kirchmann, H., and Haberhauer, G.: The response of soil organic matter to manure amendments in a long-term experiment at Ultuna, Sweden, Eur. J. Soil Sci., 48, 273-282, 1997.

Giardina, C. P. and Ryan, M. G.: Evidence that decomposition rates of organic matter in mineral soil do not vary with temperature, Nature, 404, 858-861, 2000.

Heimann, M. and Reichstein, M.: Terrestrial ecosystem carbon dynamics and climate feedbacks, Nature, 451, 289-292, 2008.

Houot, S., Molina, J. A. E., Chaussod, R., and Clapp, C. E.: Simulation by NC-Soil of net mineralization in soils from the Dehérain and 36 parcelles fields at Grignon, Soil Sci. Soc. Am. J., 53, 451$455,1989$.

Hyvönen, R., Ågren, G. I., and Andrén, O.: Modelling long-term carbon and nitrogen dynamics in an arable soil receiving organic matter, Ecol. Appl., 6, 1345-1354, 1996.

Jackson, R. B., Canadell, J., Ehleringer, J. R., Mooney, H. A., Sala, O. E., and Schulze, E. D.: A global analysis of root distributions for terrestrial biomes, Oecologia, 108, 389-411, 1996.

Jenkinson, D. S.: The Accumulation of Organic Matter in Soil Left Uncultivated, Rothamsted Experimental Station Report for 1970, Part 2, 113-137, Lawes Agricultural Trust, Harpenden, UK, 1971.

Jenkinson, D. S., Poulton, P. R., and Bryant, C.: The turnover of organic carbon in subsoils. Part 1. Natural and bomb radiocarbon in soil profiles from the Rothamsted long-term field experiments, Eur. J. Soil Sci., 59, 391-399, 2008.

Jobaggy, E. G. and Jackson, R. B.: The vertical distribution of soil organic carbon and its relation to climate and vegetation, Ecol. Appl., 10, 423-436, 2000.

Johnston, A. E., Poulton, P. R., and Coleman, K.: Soil Organic Matter: its Importance in Sustainable Agriculture and Carbon 
Dioxide Fluxes, Adv. Agron., 101, 1-57, 2009.

Kelly, R. H., Parton, W. J., Crocker, G. J., Grace, P. R., Klir, J., Korschens, M., Poulton, P.R. and Richter, D.D.: Simulating trends in soil organic carbon in long-term experiments using the century model, Geoderma, 81, 75-90, 1997.

Kiem, R., Knicker, H., and Kögel-Knabner, I.: Refractory organic carbon in particle-size fractions of arable soils I: distribution of refractory carbon between the size fractions, Org. Geochem., 33, 1683-1697, 2002.

Kiem, R. and Kögel-Knabner, I.: Refractory organic carbon in particle-size fractions of arable soils II: organic carbon in relation to mineral surface area and iron oxides in fractions $<6 \mu \mathrm{m}$, Org. Geochem., 33, 1699-1713, 2002.

Kirchmann, H., Persson, J., and Carlgren, K.: The Ultuna long-term soil organic matter experiment, 1956-1991, Department of Soil Sciences, Reports and Dissertations, 17, Swedish University of Agricultural Sciences, Uppsala, Sweden, 1994.

Kirchmann, H., Pichlmayer, F., and Gerzabek, M. H.: Sulfur balances und Sulfur-34 abundance in a long-term ferilizer experiment, Soil Sci. Soc. Am. J., 59, 174-178, 1996.

Knorr, W., Prentice, I. C., House, J. I., and Holland, E. A.: Longterm sensitivity of soil carbon turnover to warming, Nature, 433, 298-301, 2005.

Lazarev, V. I.: Dynamics of agro-physical soil properties, in: Dynamics of effective fertility of chernozem under long-term agricultural use, Kursk, Kursk State Agricultural Academy (in Russian), 89-94, 2007.

Lehmann, J., Skjemstad, J., Sohi, S., Carter, J., Barson, M., Falloon, P., Coleman, K., Woodbury, P., and Krull E.: Australian climate-carbon cycle feedback reduced by soil black carbon, Nat. Geosci., 1, 832-835, 2008.

Morel, R., Lasnier, T., and Bourgeois, P.: Les essais de fertilisation de longue durée de la station agronomique de Grignon; Dispositif Dehérain et des 36 Parcelles: Résultats expérimentaux (période 1938-1982), Institut National de la Recherche Agronomique, Paris, 335p, 1984.

Parton, W. J., Schimel, D. S., Cole, C. V., and Ojima, D.,S.: Analysis of factors controlling soil organic matter levels in great plains grasslands, Soil Sci. Soc. Am. J., 51, 1173-1179, 1987.

Paustian, K., Parton, W. J., and Persson, J.: Modeling soil organic matter in organic-amended and nitrogen-fertilized longterm plots, Soil Sci. Soc. Am. J., 56, 476-488, 1992.
Penman, H. L.: Natural evaporation from open water, bare soil and grass, Proc. R. Soc. Lon. Ser-A, 193, 120-146, 1948.

Pernes-Bebuyser, A. and Tessier, D.: Influence du $\mathrm{pH}$ sur les propriétés des sols : l'essai de longue durée des 42 parcelles à Versailles, Revue de Sciences de l'Eau, 15, 27-39, 2002.

Petersen, B. M., Berntsen, J., Hansen, S., and Jensen, L. S.: CNSIM - a model for the turnover of soil organic matter, I. Longterm carbon and radiocarbon development, Soil Biol. Biochem., 37, 359-374, 2005.

Plante, A. F., Pernes, M., and Chenu, C.: Changes in clayassociated organic matter quality in a $\mathrm{C}$ depletion sequence as measured by differential thermal analyses, Geoderma, 129, 186199, 2005.

Reichstein, M., Kätterer, T., Andrén, O., Ciais, P., Schulze, E.-D., Cramer, W., Papale, D., and Valentini, R.: Temperature sensitivity of decomposition in relation to soil organic matter pools: critique and outlook, Biogeosciences, 2, 317-321, doi:10.5194/bg2-317-2005, 2005.

Santaren, D., Peylin, P., Viovy, N., and Ciais, P.: Optimizing a process-based ecosystem model with eddy-covariance flux measurements: A pine forest in southern France, Global Biogeochem. Cy., 21, GB2013, doi:10.1029/2006GB002834, 2007.

Sitch, S., Huntingford, C., Gedney, N., Levy, P. E., Lomas, M., Piao, S. L., Betts, R., Ciais, P., Cox, P., Friedlingstein, P., Jones, C. D., Prentice, I. C., and Woodward, F. I.: Evaluation of the terrestrial carbon cycle, future plant geography and climate-carbon cycle feedbacks using five Dynamic Global Vegetation Models (DGVMs), Global Change Biol., 14, 2015-2039, 2008.

Tarantola, A.: Inverse Problem Theory: Methods of Data Fitting and Model Parameter Estimation, Elsevier Science Ltd, pp 630, 1987.

Trumbore, S. E.: Potential responses of soil organic carbon to global environmental change, Proc. Nat. Ac. Sci., 94, 8284-8291, 1997.

Von Lützow, M., Kögel-Knabner, I., Ludwig, B., Matzner, E., Flessa, H., Ekschmitt, K., Guggenberger, G., Marschner, B. and Kalbitz, K.: Stabilization mechanisms of organic matter in four temperate soils: Development and application of a conceptual model, J. Plant Nutr. Soil Sci., 171, 111-124, 2008. 